\title{
Ontogeny of Embryonic Chicken Lung: Effects of Pituitary Gland, Corticosterone, and Other Hormones upon Pulmonary Growth and Synthesis of Surfactant Phospholipids
}

\author{
VinCENT W. HylkA ${ }^{1}$ AND Byron A. DONFFen ${ }^{2}$ \\ Division of Biological Sciences, University of Michigan, Ann Arbor, Michigan 48109
}

Accepted Octobcr 18, 1982

\begin{abstract}
The actions of hormones on growth, cellular proliferation, and on synthetic rates of the major surfactant phospholipids, phosphatidylcholine (PC) and disaturated PC (DSPC), were studied in the lung of the chick embryo. Particular emphasis was placed on the effects of hypophysectomy, pituitary transplantation, and treatment with corticosterone (CORT). One study was concerned with hydrocortisone (HYCORT), estrogen $\left(E_{2}\right)$, thyroxine $\left(\mathrm{T}_{4}\right)$, ovine prolactin (oPRL), and insulin. Hypophysectomy interfered with the normal gain in protein, the progressive dehydration of the embryonic lung, and also caused a reduction in the number of pulmonary cells on Days 16 and 18 of incubation. Absence of the pituitary gland diminished pulmonary PC by Day 16. Transplantation of one pituitary gland or exogenous CORT partially restored pulmonary phospholipid and PC (normalized per wet weight) in hypophysectomized (hypox) embryos. Transplantation also restored relative protein content in lungs of hypox individuals. Beyond this, transplantation was generally ineffective in reversing deficits of hypox individuals. All concentrations of CORT administered (30$100-300 \mu \mathrm{g}$ ) reduced the rate of pulmonary cell division. The highest dose was toxic as judged by its capacity to cause cellular death. Treatment of intact chicken embryos with CORT or $E_{2}$ for two days stimulated incorporation of $\left[{ }^{14} \mathrm{C}\right]$ choline into PC and DSPC (the most surface-active component of PC) in the lungs of Day 17 embryos. CORT, but not $E_{2}$. stimulated DSPC synthesis when treatment was increased to 3 days. Other hormones tested ( $\mathrm{T}_{4}$, oPRL, insulin, and HYCORT) had no effect upon the rate of incorporation of $\left[{ }^{14} \mathrm{C}\right] \mathrm{choline}$ into PC or DSPC. These results indicate that during ontogeny the avian lung becomes sensitive to CORT, and possibly $E_{2}$, prior to 16 days of incubation. CORT, in particular, acts both to trigger the prehatching stimulation of surfactant phospholipid synthesis, especially the vital DSPC fraction, and to slow the rate of pulmonary cellular division coincident with biochemical differentiation of the surfactant system.
\end{abstract}

The air spaces of the avian and mammalian lung are lined with surfactant. This phospholipid-enriched secretion reduces surface tension, thus promoting pulmonary stability during breathing (Pattle, 1978). As in mammals, the major class of phospholipid in avian surfactant is phosphatidylcholine (PC). Quantitatively, the most important PC subcomponent is disaturated phosphatidylcholine (DSPC) (Fujiwara et al.,

\footnotetext{
${ }^{1}$ Present address: Department of Physiology, Michigan State University, E. Lansing, Mich. 48824.

2 'lo whom reprint requests should be addressed: Division of Biological Sciences, The University of Michigan, Ann Arbor, Mich. 48109.
}

1970; Hylka and Doneen, 1982). The spatial characteristics of the saturated 16-carbon fatty acid side-chains of DSPC are believed to be responsible for the potent surface-active properties of surfactant (Massoro, 1981). In the avian embryo both content and synthesis of pulmonary PC and DSPC increase prior to pipping which signals the onset of breathing (Tordet and Marin, 1976; Hylka and Doneen, 1982). A marked accumulation of surfactant also occurs in the mammalian fetal lung in the days preceding parturition (Van Golde, 1976).

Blackburn and coworkers $(1972 ; 1973)$ showed in the fetal rat that absence of the 
pituitary gland, or deficits in hormones released in response to trophic pituitary agents, inhibited normal pulmonary growth. Many subsequent studies have identified specific hormones which promote growth and differentiation of the mammalian fetal lung. Most work has focused on the ability of glucocorticoids to accelerate both morphological and biochemical aspects of pulmonary development, particularly the ability of cortisol to stimulate surfactant synthesis and release (Ballard, 1981). Other hormones, such as estrogen, thyroid hormones, and, less certainly, prolactin, have also been implicated in maturation of the fetal pulmonary surfactant system (Smith and Bogues, 1980; Ballard, 1981).

The chick embryo possesses certain experimental advantages not possessed by the fetus; these include the possibility of longterm pituitary ablation, ease of access for administration of hormones, and isolation from immediate maternal endocrine influences. Nonetheless, identification of hormones which regulate pulmonary growth, maturation, and synthesis of surfactant in the avian embryo has not been achieved. Some experiments have suggested important roles for pituitary and adrenal hormones in ontogeny of the avian lung. For example, hypophysectomy of the chicken embryo by partial decapitation delayed the appearance of surfactant-secreting type II cells (Marin and Dameron, 1974; Marin et al., 1978) and reduced content of $\mathrm{PC}$ in the lungs of embryos (Hylka and Doneen, 1980). Furthermore, organelles specialized for surfactant synthesis and storage (lamellar bodies) in type II cells could be stimulated to appear in lungs of hypophysectomized embryos when cocultured with either pituitary or adrenal glands (Dameron and Marin, 1978). Other evidence that hormones may be important in the development of avian surfactant is less direct. We have shown that content and synthesis of PC and DSPC increased most rapidly in the lung of the chicken embryo after Day 18 of incubation
(Hylka and Doneen, 1980; 1982), which coincides with peak titers of plasma corticoids (Kalliecharan and Hall, 1974; MarieSchlienger and Idelman, 1981), thyroid hormones (Thommes and Hylka, 1977; Bacou et al., 1979), and prolactin (Harvey et al., 1979). Though these findings are compatible with several hormones having roles in growth regulation of the embryonic lung, or in differentiation of its capacity to produce surfactant, no studies have investigated the effects of specific agents.

This paper reports the influences of hypophysectomy, pituitary replacement, and administration of corticosterone acetate upon growth, cellular proliferation, and differentiation of surfactant synthesis in the lung of the chick embryo. In addition, the actions of insulin, thyroxine, prolactin, and estrogen on the synthesis of the major surfactant phospholipids, PC and DSPC, were observed.

\section{MATERIALS AND METHODS}

Operations. Fertilized eggs (Rhode Island Red $\times$ White Leghorn) were obtained from Dave's Eggs and Poultry (Ann Arbor, Mich.). Ail eggs were incubated at $37.7 \pm 0.7^{\circ}$ in a forced-draft, rocking incubator. In experiments involving hypophysectomy or administration of homones, a small hole (window) was made in the egg shell directly above the embryo on Days 12 of incubation. The window provided access for partial decapitation of the embryo, or for the later addition of hormones to the chorioallantoic membrane (CAM). The hole was taped and eggs were transferred to a stationary incubator $\left(37.7^{\circ}\right)$ for the duration of the experiment. At the conclusion of the incubation period, lungs were quickly dissected, blotted, weighed, wrapped in aluminum foil, and quick-frozen in a dryice ethanol bath. Tissues were stored at $-25^{\circ}$ until analyzed.

Embryos were hypophysectomized at 33-38 hr of incubation by the method of partial decapitation (Fugo, 1940). Incompletely decapitated embryos those with remnants of eyes or upper beak) were not included in any of the results. Control embryos received a windowed shell, but were otherwise not operated upon. In transplantation expcriments, single pituitary glands from 10-day-old donor embryos were transplanted onto the CAM of 9-day-old hypophysectomized (hypox) recipients (Betz, 1967). At sacrifice, transplanted pituitaries were examined with a dissecting microscope to determine viability of the gland (as judged by exteri- 
sive vascularization of transplant). Eggs containing nonviable transplants were discarded.

Hormone administration. The first set of experiments compared various markers of pulmonary growth in windowed controls and in hypophysectomized (hypox) embryos subjected to pituitary or to corticosterone (CORT) replacement. Animals received $100 \mu \mathrm{l}$ of hormone solution on Days 13, 14, and 15 of incubation by direct addition to the CAM. Corticosterone21-acetate (Sigma Chemical Co.) was dissolved in a small volume of warm $95 \%$ ethanol and diluted with $0.9 \%$ sterile saline to form a fine suspension (final ethanol $=3 \%$ ). Three concentrations of CORT (30, 100 , and $300 \mu \mathrm{g}$ ) were administered daily. Control treatment consisted of $0.9 \%$ sterile saline with $3 \%$ ethanol.

In experiments which measured in vitro incorporation of $\left[{ }^{14} \mathrm{C}\right]$ choline into phospholipids of lung slices, hormones were administered to embryos as described above. Two incorporation experiments were performed. In the first (Table 5), embryos were treated on Days 15 and 16 of incubation and lungs were dissected for in vitro exposure to labeled precursor on Day 17. The following hormones and control substances were administered daily: $20 \mu \mathrm{g}$ corticosterone-21-acetate (CORT: Sigma), $20 \mu \mathrm{g}$ 17- $\beta$-estradiol ( $\mathrm{E}_{2}$, Sigma), 20 $\mu \mathrm{g}$ cholesterol (Supelco), $20 \mu \mathrm{g}$ bovine insulin (Sigma), $20 \mu \mathrm{g}$ ovine prolactin (oPRL; $35 \mathrm{IU} / \mathrm{mg}$; NIH-P-S12), $100 \mathrm{ng}$ L-thyroxine $\left(\mathrm{T}_{4} ;\right.$ Sigma), $0.9 \% \mathrm{NaCl}$. CORT and $\mathrm{T}_{4}$ were also given in combination. As shown previously by induction of specific physiological responses, protein hormones, like the more lipophilic agents, enter the embryonic circulation after topical application onto the CAM, though the efficiency of transfer is not known (insulin: Thommes and Tamborino, 1962; prolactin: Doneen and Smith, 1982b). In the second experiment (Table 6), embryos were treated with hormones on Days 14,15 , and 16 , and lungs from these were also removed on Day 17 of incubation. In this experiment, $20 \mu \mathrm{g}$ CORT, $20 \mu \mathrm{g}$ hydrocortisone (HYCORT; Sigma), $20 \mu \mathrm{g} \mathrm{E}_{2}$, and $20 \mu \mathrm{g}$ cholesterol were administered daily. In both experiments, control embryos received $100 \mu \mathrm{l}$ of either $0.9 \% \mathrm{NaCl}(3 \%$ ethanol) or a suspension of $20 \mu \mathrm{g}$ cholesterol in $0.9 \% \mathrm{NaCl}$ (3\% ethanol). Cholesterol served as the steroid control. Since results from administration of saline and cholesterol did not differ ( $t$ test, $P<0.05$ ), these values were pooled to form a single control group.

Lipid isolation and analysis. Lipids were extracted by homogenization in $20 \mathrm{vol}$ of chloroform:methanol (2:1) according to Folch et al. (1957). Total extracted fat was measured gravimetrically, following evaporation of solvent and overnight desiccation in vacuo over $\mathrm{KOH}$. Phospholipid content was estimated by measuring phosphorous (Bartlett, 1959) in lipid digests as described previously (Hylka and Doneen, 1982).

Individual phospholipid were separated by thin-layer chromatography using chloroform:methanol:0.25\%
KCl:2-propanol:triethylamine (30:9:6:25:18; Touchstone et al., 1980). Visualization and elution of phospholipids has been previously described (Hylka and Doneen, 1982). Disaturated phosphatidylcholine (DSPC) was isolated by silica gel chromatography after reacting phospholipids with osmium tetroxide (Mason et al., 1976). The use of this method to isolate DSPC from avian lungs with $>95 \%$ recovery has been verified (Hylka and Doneen, 1982).

Methods for measuring both $\left[{ }^{14} \mathrm{C}\right]$ choline incorporation into lung $\mathrm{PC}$ and $\mathrm{DSPC}$ in vitro and tissue choline specific activity (choline acetyl transferase assay) have been previously described in detail (Hylka and Doneen, 1982).

Protein, dry weight, water content. Protein was estimated in lung homogenates according to Lowry et al. (1951) using bovine serum albumin (Sigma) as standard. Tissue dry weight was determined by adding total lipid weight and lean dry weight (Marin et al., 1978). Pulmonary water content was calculated by subtracting dry weight from wet weight.

DNA analysis. Lungs were homogenized in $10 \mathrm{vol}$ of water and DNA content was measured in a $50-\mu 1$ aliquot using diphenylamine (Burton, 1956) with calf thymus DNA (Sigma) as standard. The number of cells was estimated using the value of $2.573 \times 10^{-6} \mu \mathrm{g}$ DNA/chicken cell (Fasman, 1976).

Measurement of cell death. Cell death after treatment with CORT was measured from the loss of radioactivity in the DNA fraction isolated from lung cells previously labeled with $\left[{ }^{3} \mathrm{H}\right]$ thymidine. Methyl $\left[{ }^{3} \mathrm{H}\right]-$ thymidine (New England Nuclear; $4.6 \mathrm{Ci} / \mathrm{mmol}$ ) in $70 \%$ ethanol was evaporated to a small volume and diluted with sterile isotonic saline (final concentration: $5 \%$ ethanol). One hundred microliters of $\left[^{3} \mathrm{H}\right]$ thymidine $(6.7$ $\mu \mathrm{Ci}$ ) were added to the CAM on Day 10 of incubation. CORT or saline-ETOH was subsequently administered on Days 13,14, and 15 as described above. On Day 13, lungs from several embryos not treated with hormones were collected for measurement of label incorporated. Cell death occurring by Day 16 was estimated from the percent label remaining compared with pretreatment (Day 13) values (i.e., no loss of cells = $100 \%$ of the $\left[{ }^{3} \mathrm{H}\right]$ thymidine incorporated on Day 13 remained on Day 16). DNA was measured in lungs of 16-day embryos as described above. A second aliquot $(100 \mu l)$ was pipetted onto a $2.3-\mathrm{cm}$ Whatman No. 3 filter paper disk for measurement of ${ }^{3} \mathrm{H}$ incorporated into DNA (Fong and Bockrath, 1977). DNA was precipitated by immersing filters overnight in a beaker of ice-cold 5\% trichloroacetic acid (TCA). These were then washed twice with 5\% TCA and once each in $100 \%$ ethanol and acetone. Disks were dried and radioactivity was counted by placing disks in $10 \mathrm{ml}$ of OCS (Amersham) scintillation fluid.

Statistics. Significance of differences between mean values was determined using either Students' $t$ test or, in cases in which multiple comparisons were made, 
from analysis of variance followed by Duncan's new multiple-range test, Dunnett's test, or the least-significant-difference (1sd) method (Steel and Torrie, 1980). The acceptance level for significance was set at 0.05 .

\section{RESULTS}

The effects of hypophysectomy, and of hypophysectomy with CORT treatment or pituitary replacement, upon wet weight, hydration, and protein content in lungs of chicken embryos on Day 16 of development are summarized in Table 1. Pulmonary wet weight in hypox embryos was not different from windowed embryos. Administration of CORT, however, reduced pulmonary wet weight in a dose-dependent manner in both hypox (Table 1) and also in intact embryos (data not shown). Lung water as a percentage of the wet weight was increased in hypox embryos compared with the nonoperated $(\mathrm{W}+\mathrm{V})$ group $(P<0.05)$. Treatment with CORT significantly reduced pulmonary hydration in hypox animals, $(P<$ 0.05 ), but hypophyseal replacement was ineffective. Hypox embryos also exhibited lowered pulmonary protein compared with $\mathrm{W}+\mathrm{V}$ individuals. Pituitary transplantation restored protein to normal levels (when normalized to dry weight) in lungs of hypox embryos, whereas treatment with CORT had no similar effect.

The numbers of cells in lungs of intact and hypox embryos between Days 12-20 of incubation are illustrated in Fig. 1. Normal embryos exhibited three phases of pulmonary growth in this interval. The most rapid phase (Days 14-18) was bracketed by periods of relatively slower growth. On Day 12 , lungs from hypox individuals contained significantly more cells compared with lungs of W embryos $(p<0.05)$. After Day 12, however, pulmonary growth rate in hypox animals was slowed compared with intact individuals, but only until Day 16 of incubation. Between Days 16 and 18, the rate of increase in the number of cells was only modestly reduced in hypox embryos compared with $\mathrm{W}$ individuals. Transplantation of a single pituitary gland into hypox embryos beginning on Day 9 of incubation did not restore numbers of pulmonary cellis to $W$ values on the one day of incubation examined (Day 16).

Tables 2 and 3 illustrate the effects of hypophysectomy and treatment with three doses of CORT upon cell number (Table 2)

TABLE 1

Pulmonary Wet Weight and Contents of Water and Protein in the 16-Day Normal and in HyPopHyseCtomized CHICKEN EMBryos AFTER TREATMENT WITH CORTICOSTERONE-21-ACETAILE or Pituitary RePlacement ${ }^{a}$

\begin{tabular}{lrccccc}
\hline \multicolumn{1}{c}{ Treatment ${ }^{h, c}$} & $(N)$ & $\begin{array}{c}\text { Lung } \\
\text { wet weight }(\mathrm{mg})\end{array}$ & $(N)$ & $\begin{array}{c}\text { Lung } \mathrm{H}_{2} \mathrm{O}: \% \\
\text { of wet weight }\end{array}$ & $(N)$ & $\begin{array}{c}\text { Protein per } \\
\text { dry weight }(\mathrm{mg} / \mathrm{mg})\end{array}$ \\
\hline Hypox $+\mathrm{V}$ & $(13)$ & $151 \pm 7$ & $(6)$ & $92.7 \pm 0.8$ & $(5)$ & $0.70 \pm 0.03$ \\
Hypox $+30 \mu \mathrm{g}$ CORT & $(12)$ & $116 \pm 9^{*}$ & $(6)$ & $90.0 \pm 0.06^{*}$ & $(6)$ & $0.75 \pm 0.01^{\text {ns }}$ \\
Hypox $+100 \mu \mathrm{g}$ CORT & $(8)$ & $75 \pm 6^{*}$ & $(6)$ & $90.5 \pm 0.4^{*}$ & $(6)$ & $0.67 \pm 0.03^{\text {ns }}$ \\
Hypox $+300 \mu \mathrm{g}$ CORT & $(15)$ & $57 \pm 3^{*}$ & $(6)$ & $88.4 \pm 0.2^{*}$ & $(6)$ & $0.69 \pm 0.02^{\mathrm{ns}}$ \\
Hypox + PIT & $(8)$ & $139 \pm 10^{\text {ns }}$ & $(6)$ & $91.4 \pm 0.4^{\text {ns }}$ & $(6)$ & $0.91 \pm 0.03^{*}$ \\
W $+\mathrm{V}$ & $(11)$ & $145 \pm 7^{\text {ms }}$ & $(5)$ & $87.0 \pm 0.3^{*}$ & $(5)$ & $0.86 \pm 0.03^{*}$ \\
& & $(F=34.43)$ & & $(F=17.13)$ & & $(F=15.98)$ \\
\hline
\end{tabular}

\footnotetext{
${ }^{a}$ Values are means \pm standard error of $N$ individual samples.

${ }^{b}$ Abbreviations, CORT: corticosterone-21-acetate, Hypox: hypophysectomized, $N$ : number of samples, PT: pituitary transplantation, $\mathrm{V}$ : vehicle, and $\mathrm{W}$ : windowed controls.

${ }^{c}$ In each column, statistical comparisons were made between all treatment groups and Hypox $+\mathrm{V}$ (control). Also shown are values of the $\mathrm{W}+\mathrm{V}$ group to indicate the state of unoperated embryos. Duncan's multiple range test was used, and $F$ value for analysis of variance is given at the bottom of each column.

${ }^{*} P<0.05$; ns, not significantly different from controls.
} 


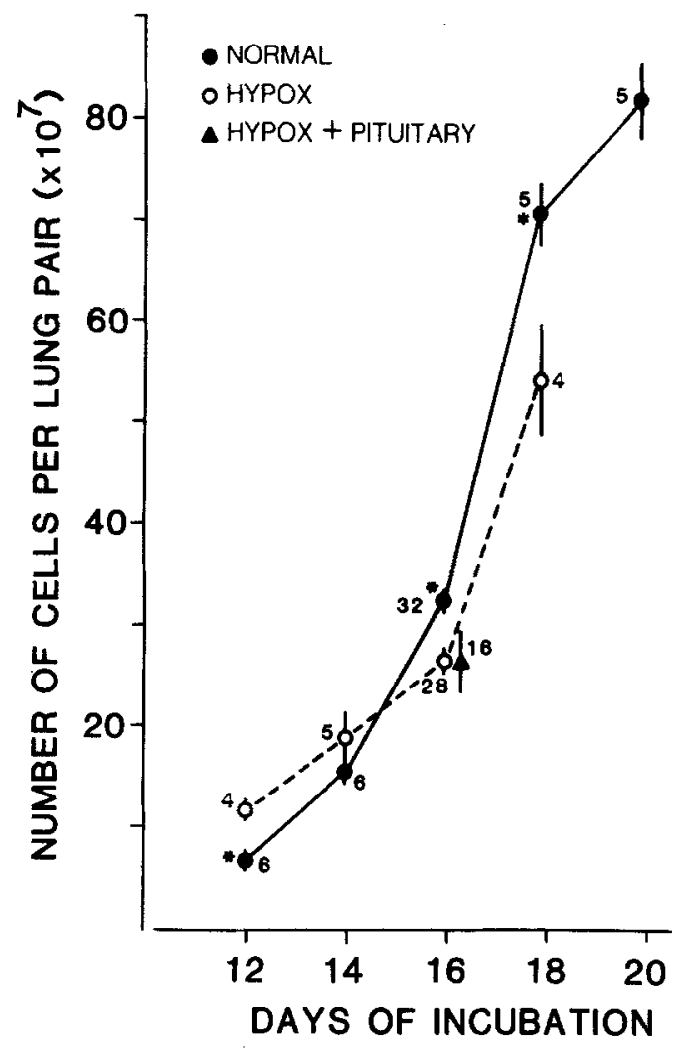

FIG. 1. Ontogeny of cell number in lungs of normal, hypophysectomized, and hypophysectomized chicken embryos receiving pituitary transplants. Values are means \pm standard error (vertical bars). Sample size is indicated next to the symbols. Asterisks indicate that control values were significantly different $(P<$ 0.05 ) from values for Hypox lungs on the same day of incubation ( $t$ test). Hypox $=$ hypophysectomized.

and cell death (Table 3) in lungs. On Day 13 of incubation, no significant difference in cell number was observed between intact and hypox embryos. When measured after 3 days of treatment with CORT (Day 1315), the two lowest doses (30 and $100 \mu \mathrm{g}$ ) permitted pulmonary growth in intact and hypox embryos as estimated from cell number, which exceeded Day 13 pretreatment values $(p<0.05$, Dunnett's Test). However, CORT in amounts of $100(\mathrm{~W})$ or $300 \mu \mathrm{g}$ (W and HYPOX), when administered for 3 days, decreased the number of pulmonary cells on Day 16 compared with saline-treated embryos in both groups. In contrast, the lowest dose of CORT $(30 \mu \mathrm{g})$ permitted the normal increase in cell number to occur between Days 13-16 in both normal and hypox animals. It should be noted that CORT or hypophysectomy did not produce tissue-specific responses in lung growth. That is, absence of the pituitary and hormone treatment also reduced general body growth of the embryo (data not shown).

Estimation of cellular death measured from the disappearance of thymidine-labeled DNA in the lungs of intact embryos after treatment with different doses of CORT is presented in Table 3. Three hundred micrograms CORT produced a significant loss $(22.1 \% ; P<0.05)$ of prelabeled cells. The reduction in $\left[{ }^{3} \mathrm{H}\right]$ thymidine activity can be associated with the actual death of cells, rather than with cell turnover, since the total number of pulmonary cells was sharply reduced in response to the highest concentration of CORT (Table 2). The intermediate dose of CORT $(100 \mu \mathrm{g})$ did not elicit cell death, but it was effective in attenuation of total cell number compared with untreated embryos in $\mathrm{W}$ and hypox groups (Table 2). Therefore, this level of CORT acted specifically to reduce the rate of cellular proliferation in the lung. In contrast, the lowest dose of CORT did not produce significant cellular death, and also permitted the normal increase in cell number (Table 2).

The effects of hypophysectomy, and of hypophysectomy with CORT treatment or pituitary transplantation, upon pulmonary lipid content are shown in Table 4. In lungs of hypox embryos, content of total lipid, total lipid phosphorous, and PC were significantly below levels observed in intact embryos $(P<0.05)$. However, treatment with CORT restored, or partially restored, these values in hypox groups. Transplantation of one pituitary gland onto the CAM of hypox embryos also produced significant elevations of total lipid, phospholipid, and PC after correction for differences in pulmonary wet weight. 
TABLE 2

The Effect of Various Doses of Corticosterone Acetate on Number of Cells in the Lung of the Normal and HyPOPHYSECTOMIZED CHICKEN EMBRYo

\begin{tabular}{|c|c|c|c|}
\hline $\begin{array}{l}\text { Day of } \\
\text { incubation }\end{array}$ & Treatment $^{a}$ & $N^{b}$ & $\begin{array}{l}\text { Number of cells per } \\
\text { lung pair }\left(\times 10^{7}\right)^{c}\end{array}$ \\
\hline 13 & W (controls) & 17 & $9.99 \pm 0.51$ \\
\hline 13 & Hypox & 6 & $10.80 \pm 0.47^{\mathrm{ns}}$ \\
\hline 16 & $W+V$ (controls) & 17 & $29.93 \pm 1.09$ \\
\hline 16 & $\mathrm{~W}+30 \mu \mathrm{g}$ CORT & 11 & $24.33 \pm 1.63$ \\
\hline 16 & $\mathrm{~W}+100 \mu \mathrm{g}$ CORT & 11 & $19.51 \pm 1.67^{*} \quad F=52.2$ \\
\hline 16 & $\mathrm{~W}+300 \mu \mathrm{g}$ CORT & 20 & $12.40 \pm 0.54^{*}$ \\
\hline 16 & Hypox $+V$ (controls) & 12 & $22.70=1.79$ \\
\hline 16 & Hypox $+30 \mu \mathrm{g}$ CORT & 6 & $23.51 \pm 2.29$ \\
\hline 16 & Hypox $+100 \mu g$ CORT & 6 & $15.12 \pm 1.20 \quad \Gamma=16.4$ \\
\hline 16 & Hypox $+300 \mu \mathrm{g}$ CORT & 13 & $12.48 \pm 0.51^{*}$ \\
\hline
\end{tabular}

${ }^{a}$ CORT: corticosterone-21-acetate, Hypox: hypophysectomized, V: vehicle, W: windowed. Hormone was given on Days 13, 14, and 15 of incubation.

${ }^{b} N=$ number of individual lung pairs.

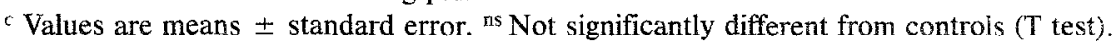

* Significantly different $(P<0.05)$ from control values. (Dunnett's Test).

The rates of incorporation of $\left[{ }^{14} \mathrm{C}\right]$ choline in vitro into pulmonary $\mathrm{PC}$ and $\mathrm{DSPC}$ following 2 days of treatment with various hormones are summarized in Table 5. The synthetic rates of both PC and DSPC were stimulated by treatment with CORT or $\mathrm{E}_{2}$ $(P<0.05)$. Prolactin, $\mathrm{T}_{4}$, and insulin had no statistically significant effect upon the synthetic rate of either phospholipid. The addition of $\mathrm{T}_{4}$ in combination with CORT reduced the synthesis of both $\mathrm{PC}$ and DSPC to a rate intermediate between that of the control and CORT groups. The fraction of newly synthesized PC contributed by the DSPC subcomponent was similar in all treatment groups (19.5-21.9\%).

Incorporation of $\left[{ }^{14} \mathrm{C}\right]$ choline into $\mathrm{PC}$ and DSPC by lung slices from 17-day embryonic chickens after 3 days treatment with CORT, HYCORT, and $\mathrm{E}_{2}$ is presented in Table 6. In this experiment, the two adrenal corticoids and $\mathrm{E}_{2}$ did not alter the synthetic rate of pulmonary PC on Day 17. However, synthesis of the DSPC component was specifically stimulated by administration of CORT $(P<0.05)$; HYCORT or $\mathrm{E}_{2}$ had no

TARLE 3

Measurement of Cellular Death in the Embryonic Avian Lung after Administration of CORTICOSTERONE-21-ACETATE

\begin{tabular}{clrc}
$\begin{array}{c}\text { Day of } \\
\text { incubation }\end{array}$ & \multicolumn{1}{c}{ Treatmenta } & $(N)$ & $\begin{array}{c}\text { \% of [ }{ }^{3} \text { H]Thymidine } \\
\text { remaining in the lung }\end{array}$ \\
\hline 13 & $\mathrm{~W}$ (control) & $(10)$ & 100.0 \\
16 & $\mathrm{~W}+\mathrm{V}$ & $(7)$ & $100.3^{\mathrm{ns}}$ \\
16 & $\mathrm{~W}+30 \mu \mathrm{g}$ CORT & $(5)$ & $102.5^{\mathrm{ns}}$ \\
16 & $\mathrm{~W}+100 \mu \mathrm{g}$ CORT & $(5)$ & $93.4^{\text {ns }}$ \\
16 & $\mathrm{~W}+300 \mu \mathrm{g}$ CORT & $(7)$ & $77^{*}$ \\
\hline
\end{tabular}

\footnotetext{
a Hormone was administered on Days 13, 14, and 15 of incubation. Abbreviations as in Table 1.

${ }^{b}$ Mean values shown. Standard error of the mean was less than $6 \%$ of the group mean in each treatment group. "ns Not significant, Dunnett's test.

${ }^{*} P<0.05(F=3.41)$. Dunnett's test.
} 
TABLE 4

Total Pulmonary Lipid, Phospholipid, and Phosphatidylcholine in the 16-Day Normal and in the 16-Day Hypophysectomized Chicken Embryo after Treatment with Corticosterone-21-Acetate OR Pitilitary Rf.Plac.Fment ${ }^{a}$

\begin{tabular}{|c|c|c|c|c|c|c|}
\hline Treatment $^{b, c}$ & $(N)$ & $\begin{array}{c}\text { Total lipid } \\
\text { per } \mathrm{g} \\
\text { wet weight (mg) }\end{array}$ & $(N)$ & $\begin{array}{c}\text { lipid } \mathbf{P} \\
\text { per } \mathbf{g} \\
\text { wet weight }(\mu \mathrm{mol})\end{array}$ & $(N)$ & $\begin{array}{c}\text { PC per g } \\
\text { wet weight }(\mu \mathrm{mol})\end{array}$ \\
\hline Hypox $+V$ & (6) & $14.0 \pm 0.9$ & (6) & $10.10 \pm 1.03$ & (6) & $5.07 \pm 0.10$ \\
\hline Hypox $+30 \mu \mathrm{g}$ CORT & (6) & $17.7 \pm 0.8^{*}$ & (6) & $16.39 \pm 0.42^{*}$ & (6) & $6.67 \pm 0.23^{*}$ \\
\hline Hypox $+100 \mu \mathrm{g}$ CORT & (6) & $17.6 \pm 1.9^{*}$ & (6) & $18.68 \pm 0.58^{*}$ & (6) & $7.15 \pm 0.48 *$ \\
\hline Hypox + PIT & (6) & $16.3 \pm 0.9 *$ & (5) & $14.65=0.26^{*}$ & (6) & $6.70 \pm 0.18^{*}$ \\
\hline $\mathbf{W}+\mathrm{V}$ & (5) & $\begin{aligned} 22.0 & \pm 0.8^{*} \\
(F & =5.72)\end{aligned}$ & (5) & $\begin{aligned} 17.58 & \leq 0.19^{*} \\
(F & =29.23)\end{aligned}$ & (5) & $\begin{array}{c}7.46 \pm 0.12^{*} \\
(F=11.60)\end{array}$ \\
\hline
\end{tabular}

${ }^{a}$ Values are means \pm standard error of $(N)$ individual samples. Corticosterone acetate or vehicle were given on Days 13, 14, and 15 of incubation.

${ }^{b}$ Abbreviations same as in Table 1.

c In each column, statistical comparisons were made between all treatment groups and Hypox $+\mathrm{V}$ (control). Also shown are values in the $\mathrm{W}+\mathrm{V}$ group to indicate lipid content in unoperated embryos. Duncan's multiplerange test was used and $F$ value for analysis of variance is given at the bottom of each column.

$* P<0.05$.

stimulatory effect on DSPC synthesis. Furthermore, newly synthesized DSPC, as a percentage of newly synthesized PC, increased to $35 \%$ following CORT treatment

TABLE 5

INCORPORATION OF $\left[{ }^{14} \mathrm{C}\right]$ CHOLINE in Vitro INTO PC AND DSPC BY IJUNG SIICES FROM THE DAY-17 EMRRYONIC CHICKEN AFTER 2 DAYS OF HORMONE TREATMENT $^{q}$

\begin{tabular}{|c|c|c|c|}
\hline \multirow[b]{2}{*}{ Treatment $^{c}$} & \multirow[b]{2}{*}{$(N)$} & \multicolumn{2}{|c|}{$\begin{array}{l}\text { Nanomoles synthesized } \\
\text { per g protein } \cdot \mathrm{hr}^{-1 b}\end{array}$} \\
\hline & & $\mathrm{PC}$ & DSPC \\
\hline $\mathrm{W}+\mathrm{V}$ (controls) & (8) & $16.5 \pm 1.0$ & $3.5 \pm 0.4$ \\
\hline CORT $(20 \mu \mathrm{g})$ & (5) & $21.0 \pm 1.6^{*}$ & $4.6 \pm 0.4^{*}$ \\
\hline$E_{2}(20 \mu g)$ & (4) & $22.7 \pm 2.4^{*}$ & $4.9 \pm 0.5^{*}$ \\
\hline PRL $(20 \mu \mathrm{g})$ & (5) & $15.1 \pm 0.8$ & $3.2 \pm 0.3$ \\
\hline $\mathrm{T}_{4}(100 \mathrm{ng})$ & (4) & $15.3 \pm 1.8$ & $3.0 \pm 0.5$ \\
\hline CORT $(20 \mu \mathrm{g})+$ & & & \\
\hline $\mathrm{T}_{4}(100 \mathrm{ng})$ & (4) & $18.3 \pm 1.6$ & $3.9 \pm 0.5$ \\
\hline Insulin $(20 \mu \mathrm{g})$ & (4) & $\begin{aligned} 20.5 & \pm 2.3 \\
(F & =3.27)\end{aligned}$ & $\begin{array}{l}4.0 \pm 0.3 \\
\quad(F=2.70)\end{array}$ \\
\hline
\end{tabular}

"Values are means \pm standard error for $N$ individual lung pairs after $4 \mathrm{hr}$ incubation in vitro.

${ }^{b}$ Calculated from the choline specific activity determined in tissue slices. The specific activity of the choline pool was similar for lungs of all treatment groups, and averaged $9.18 \pm$ $0.06 \times 10^{3} \mathrm{dpm} / \mathrm{nmol}$ (no significant differences among groups). Significance of differences between means was made using the lsd test.

c Abbreviations: $\mathrm{PC}=$ phosphatidylcholine, DSPC $=\mathrm{di}-$ saturated phosphatidylcholine, CORT $=$ corticosterone-21acetate, $\mathrm{E}_{2}=17-\beta$-estradiol, $\mathrm{PRL}=$ prolactin, $\mathrm{T}_{4}=$ thyroxine.

$* p<0.05$. for 3 days. In contrast, only $21 \%$ of the PC synthesized in vitro was contributed by DSPC in control and in HYCORT and $\mathrm{E}_{2}$ groups $(P<0.05)$. In $\mathrm{E}_{2}$-treated embryos the specific activity of choline in lung slices was significantly reduced compared with other groups $(P<0.05)$.

\section{TABLE 6}

RATES OF INCORPORATION OF $\left[{ }^{14} \mathrm{C}\right]$ CHOLINE in Vitro INTO PC AND DSPC BY LUNG SLICES FROM THE DAY-17 EMBRYONIC CHICKEN AFTER 3 DAYS OF TREATMENT WITH VARIOUS STEROIDS ${ }^{a}$

\begin{tabular}{lrrr}
\hline & & \multicolumn{2}{c}{$\begin{array}{c}\text { Nanomoles synthesized } \\
\text { per g protein } \cdot \mathrm{hr}^{-1 b}\end{array}$} \\
\cline { 3 - 4 } \multicolumn{1}{c}{ Treatment $^{c}$} & & $(N)$ & \multicolumn{2}{c}{ PC } & DSPC \\
\hline $\mathrm{W}+\mathrm{V}$ (controls) & $(15)$ & $16.6 \pm 0.6$ & $3.5 \pm 0.2$ \\
CORT (20 $\mu \mathrm{g})$ & $(7)$ & $16.0 \pm 1.8$ & $5.6 \pm 0.6^{*}$ \\
HYCORT $(20 \mu \mathrm{g})$ & $(7)$ & $16.9 \pm 1.4$ & $4.1 \pm 0.4$ \\
$\mathrm{E}_{2}(20 \mu \mathrm{g})$ & $(8)$ & $16.4 \pm 1.2$ & $3.5 \pm 0.4$ \\
& & $(F=0.035)$ & $(F=6.56)$ \\
\hline
\end{tabular}

a Values are means \pm standard error for $N$ lung pairs after $4 \mathrm{hr}$ incubation in vitro.

${ }^{b}$ Calculated from choline specific activity determined in tissue slices. Specific activities (expressed as $\mathrm{dpm} / \mathrm{nmol}$ choline $\times 10^{3}$ ) were: controls $-11.5 \pm 0.70$; corticosterone -11.42 \pm 0.56 ; hydrocortisone $-11.23 \pm 0.68 ; 17-\beta$-estradiol -9.63 \pm 0.58 .

${ }^{c}$ Abbreviations: CORT $=$ corticosterone-21-acetate, $\mathrm{HY}$ CORT $=$ hydrocortisone, $E_{2}=17$ - $\beta$-estradiol .

* Significantly different from control values $(P<0.05)$ (lsd test). 


\section{DISCUSSION}

These results show that pituitary hormones and corticosterone can influence growth, hydration, and lipid content of the lung of the chicken embryo. Of the specific hormones examined, CORT had the most prominent effects, both on pulmonary growth and on surfactant synthesis. CORT given alone, however, did not correct all biochemical and growth impairments observed in the lung of the hypox embryo, and was toxic when given in sufficiently high amounts.

Hormones can act on pulmonary growth in many ways. Since increased content of surfactant lipid in ontogeny has usually been normalized to protein, wet weight, dry weight, or DNA, possible independent actions of hormones on these aspects of lung growth must be considered.

Pulmonary growth in the chicken embryo in response to pituitary ablation and to corticosteroid or pituitary replacement has not been previously characterized. Whereas protein and wet weight did not attain normal levels in the lungs of Day 16 hypox embryos, pulmonary water as a percentage of the wet weight was greater than in lungs of intact controls. Pulmonary hydration in hypox embryos might have been associated with changed water permeability of lung cells, or to increased water in extracellular spaces (Marin et al., 1978). Inasmuch as hydration of pulmonary cells is normally greater early in embryogenesis than later, absence of pituitary hormones or deficiencies of other hormones in hypox embryos might simply have retarded the time course of development (Hylka, 1982; Doneen and Smith, 1982a). Administration of CORT affected pulmonary weight in intact and hypox individuals (a) by reduction of water content in lungs of hypox embryos (Table 1), (b) by decreasing total number of cells when given in concentrated doses (Tables 2 and 3), and (c) by also reducing dry weight (data not shown) in the lungs of both normal and hypox individuals. CORT thus acts on several aspects of pulmonary growth. Depressed pulmonary weight after corticoid administration has also been observed in lungs of the fetal rabbit (Kotas and Avery, 1971; Carson et al., 1973; Barrada et al, 1980).

Most actions of CORT in the hypox embryo were not duplicated by transplantation of the embryonic pituitary gland. Pituitary transplantation did not reverse the high pulmonary hydration seen in hypox embryos. The inability of the transplant to duplicate these actions of CORT seems to indicate a lack of stimulation of the pituitary-adrenal axis. Although the transplant remained on the CAM for 7 days, during which time it became vascularized, the loss of hypothalamic connections apparently prevented release of pituitary hormones. It has been shown by Thommes and Jameson (1980) that although a transplanted pituitary on the CAM of a hypox chicken embryo could release TSH in response to exogenous TRH, the unstimulated pituitary could only partially restore thyroid function. Thus, the ectopic pituitary on the CAM probably produced suboptimal secretion of the pituitary hormones required for normal pulmonary growth and hydration. Another possibility is that the transplanted pituitary of the 10day-old embryo had inadequate amounts of stored hormone, or failed to synthesize the amount required, to restore normal functions in the 13-16-day embryo. On the other hand, hypophyseal secretion seemed sufficient to increase pulmonary protein in hypox embryos. Thus, separate hormones responsible for various aspects of pulmonary growth and maturation may have different magnitudes of secretion from the transplant.

Hypophysectomy produced different effects on pulmonary cell number depending on the period of development. Early in incubation (Day 12), lungs from hypox embryos contained more cells than those in unoperated animals. Similar observations 
have been made in lungs of rat fetuses decapitated 10 days prior to birth (Blackburn et al., 1972; 1973). However, by Day 16 of incubation, lungs of hypox embryos contained fewer cells than controls. Moreover, the normal rapid phase of cellular division was delayed by 2 days in the lungs of hypox embryos (Fig. 1). Thus, the pituitary apparently restrained pulmonary cell division in the chick embryo early in organogenesis, whereas the rapid phase of cellular division occurred (albeit delayed) even in the $a b$ sence of the hypophysis. Alternatively, autonomous secretion of hormones by target glands of the pituitary (i.e., adrenal, thyroid, gonads) could have been adequate for the rapid phase of pulmonary cell division.

Administration of CORT not only caused a reduction in lung size and weight in the chick embryo, but also reduced the number of cells. Although a reduced mitotic rate could account for the diminished number of cells in response to the lower doses of COR'T (30 and $100 \mu \mathrm{g}$ ), the drastic reduction in cell number in response to the 300$\mu \mathrm{g}$ dose was also accompanied by an actual loss of cells from the lung (Table 3). This proof of toxicity is important because doses as high as $1 \mathrm{mg} / \mathrm{chicken}$ embryo (Moog and Richardson, 1955; Thommes and Shulman, 1967) and $2 \mathrm{mg} / \mathrm{rabbit}$ fetus (Carson et al., 1973) have been used in previous studies. One hundred micrograms of CORT reduced the mitotic rate of the lung as inferred from the diminished number of cells compared with untreated controls, and from the absence of cellular death (Tables 2 and 3). As $100 \mu \mathrm{g}$ CORT simultaneously elevated total pulmonary phospholipid and PC content, action of the corticoid on the lung included parallel inhibition of cellular proliferation and stimulation of surfactant phospholipid production. The dual nature of corticosteroid action in the lung of the avian embryo is similar to that seen in the fetal mammal, in which cortisol inhibited increased pulmonary cell number while simultaneously promoting DSPC synthesis (Smith et al.,
1974). As in the chick embryo, physiological concentrations of glucocorticoid specifically attenuated the mitotic rate of lung cells in the fetus (Liggins and Kitterman, 1981).

Since hypophyseal and/or adrenal hormones directly stimulate the appearance of lamellar bodies in the avian embryonic lung (Dameron and Marin, 1978), it was important to correlate the effects of hormones on surfactant lipids (especially phospholipids and $\mathrm{PC}$, which are abundant in lamellar bodies) with the previous morphological findings. The reduction of pulmonary $\mathrm{PC}$ content in the hypox avian embryo (Table 4) can be related to the delayed appearance of lamellar bodies in operated individuals (Marin and Dameron, 1974). Administration of CORT, as well as transplantation of one pituitary gland, elevated all aspects of pulmonary lipid content measured (per gram wet weight) compared with hypox embryos. Elevated PC in response to hypophyseal replacement represented a genuine increase in lung content, since the transplant did not significantly alter pulmonary hydration. In hypox embryos receiving CORT, some of the increased lipid content (per unit wet weight), but not all, could be attributed to the parallel reduction in lung hydration. These results suggest that hormones of the pituitary and CORT can increase the storage of synthesis of pulmonary surfactant lipids in the avian embryo; results discussed below confirm a stimulation of synthesis.

Two days of treatment (Days 15 and 16) with either CORT or $\mathrm{E}_{2}$ increased the synthesis of PC and DSPC in the Day $17 \mathrm{em}-$ bryonic lung; other hormones (including CORT and $T_{4}$ in combination) were ineffective. However, administration of CORT or $\mathrm{E}_{2}$ one day earlier in incubation (beginning on Day 14), was ineffective in stimulating PC synthesis, although a selective and significant stimulation of DSPC synthesis occurred after treatment with CORT. The stimulation of DSPC synthesis after 3 days of CORT treatment must have occurred si- 
multaneously with decreased synthesis of other species of PC, since synthesis of total $\mathrm{PC}$ (in which DSPC is a major component) was unchanged. Thus, the effect of exogenous adrenal and gonadal steroids upon incorporation of choline into pulmonary $\mathrm{PC}$. and DSPC depends upon the specific hormone administered and the duration of treatment.

Increased content of phospholipid, and elevated synthesis of PC or DSPC in response to CORT and $\mathrm{E}_{2}$, coincided with the earliest period in ontogeny showing rising circulating titers of these two steroids (Kalliecharan and Hall, 1974; Woods and Brazzill, 1981). Tordet and Marin (1976) ohserved greater amounts of PC in lungs of female embryos (which have higher plasma $E_{2}$ ) than in males. We cannot decide if the stimulation of pulmonary PC or DSPC synthesis by two days of $E_{2}$ treatment was greater in male or female embryos since individuals used were not sexed. Our results, and the earlier finding that adrenal glands directly stimulate formation of lamellar bodies (Dameron and Marin, 1978), show that CORT promotes maturation of the surfactant system in the lung of the avian embryo. Its principal action is to specifically stimulate the synthesis of DSPC, the major surface-active component of avian surfactant (Hylka and Doneen, 1982).

Although Dameron and Marin (1978) observed a direct effect of the pituitary upon lamellar body formation, our study appears to exclude PRL (as judged by use of the ovine molecule) as the hypophyseal factor responsible. This conclusion must be considered provisional since oPRL treatment coincided with the rising circulating titer of endogenous PRL in which the prehatching peak occurs on Day 17 of incubation (Harvey et al., 1979). It seemed that PRL might act upon pulmonary lipid since this hormone favors deposition of fat in adults of several avian species (Meier and Burns, 1976). Although PRL allegedly increases pulmonary PC and DSPC in the mammalian fetus (Hamosh and Hamosh, 1977), this re. sult is now thought to have been due to a contaminant in the preparation used (CoX and Torday, 1981), possibly ACTH. The hypophyseal factor(s) that directly (in vitro) promoted differentiation of type II preumocytes in the avian embryo (Dameron and Marin, 1978) remains to be discovered. The possibility that the unperfused pituitary glands used in the coculture experiments contained a biologically significant store of adrenal steroids in blood or pituitary cells must also be eliminated.

Thyroid hormones promote maturation of the mammalian fetal lung, and $\mathrm{T}_{4}$ can stimulate both morphologic (Wu et al., 1973) and biochemical (Smith and Torday, 1974) differentiation. One action of $T_{4}$ is to increase the number of lung glucocorticoid receptors (Morishige, 1982). Peak levels of circulating $\mathrm{T}_{4}$ in the chicken embryo (Thommes et al., 1977) occur in the late embryonic period, coincident with the highest rates of pulmonary $\mathrm{PC}$ and $\mathrm{DSPC}$ synthesis (Hylka and Doneen, 1982). However, administration of $\mathrm{T}_{4}$ did not elevate synthetic rates of $\mathrm{PC}$ and DSPC in our study. Thus, $\mathrm{T}_{4}$ either does not promote this aspect of avian pulmonary maturation, or the presence of high levels of endogenous $T_{4}$ eliminated the possibility of further stimulation by added hormone.

Insulin delays maturation of the mammalian fetal lung (Smith et al., 1975;. Gross and Walker-Smith, 1978). In contrast, we observed a slight (though insignificant) increase in the synthesis of pulmonary PC and DSPC in the embryonic chicken after treatment with insulin. If insulin increased plasma free fatty acids in the avian embryo, as it does in the adult chicken (Nir and Levy, 1973), the increased precursor pool might itself stimulate synthesis of surfactant phospholipids, as has recently been shown to occur in the rat lung (Feldman et al., 1981).

Results of this study show that CORT, and possibly $\mathrm{E}_{2}$, are involved in the bio- 
chemical maturation of the surfactant system of avian lung, and that CORT also regulates proliferation of some or all types of pulmonary cells. Although glucocorticoids (Giannopoulos, 1974; Ballard and Ballard, 1974; Smith and Bogues, 1980) and estrogens (Morishige and Uetake, 1978; Khosla et al., 1980) have a direct effect upon the mammalian fetal lung, acting through specific receptors, it is not known whether this is also true for the chicken embryo. Our data, together with the coculture experiment of Dameron and Marin (1978) strongly suggest that adrenal steroids, at least, can act directly upon the avian lung.

\section{ACKNOWLEDGMENTS}

This work was supported by Rackham Dissertation and Faculty Grants. The authors express gratitude to Ms. Sandra Schaerer for typing the manuscript. Ovine prolactin was a gift of the hormone distribution officer, NIAMMD.

\section{REFERENCES}

Bacou, F., Jallageas, M., Nougues, J., and Vigneron, P. (1979). Differences sexuelles de le'evolution de la thyroxinemie chez l'embryon et le jeune poulet. C.R. Acad. Sci. (Paris) (D) 288, 1603-1605.

Ballard, P. L. (1981). Hormonal regulation of the surfactant system. In "Physiological and Biochemical Basis for Perinatal Medicine" (M. MonsetCouchard and A. Minkowski, eds.), pp. 42-53. Karger, Basel.

Ballard, P. L., and Ballard, R. A. (1974). Cytoplasmic receptor for glucocorticoids in lung of the human fetus and neonate. J. Clin. Invest. 53, 477-486.

Barrada, M. I., Blomquist, C. H., and Knotts, C. (1980). The effects of betamethasone on fetal development in the rabbit. Amer. J. Obstet. Gynecol. 136, 234-238.

Bartlett, G. R. (1959). Phosphorous assay in column chromatography. J. Biol. Chem. 234, 466-468.

Betz, T. W. (1967). The effects of embryonic pars distalis grafts on the development of hypophysectomized chick embryos. Gen. Comp. Endocrinol. 9, 172-186.

Blackburn, W. R., Kelly, J. S., Dickman, P. S., Thavers, H., Copata, M. A., and Rhoades, R. A. (1973). The role of the pituitary-adrenal-thyroid axes in lung differentiation. II. Biochemical studies of developing lung in anencephalic fetal rats. $L a b$. Invest. 28, 352-360.

Blackburn, W. R., Travers H., and Potter, D. M. (1972). The role of the pituitary-adrenal-thyroid axes in lund differentiation. I. Studies of cytology and physical properties of anencephalic fetal rat lung. Lab. Invest. 26, 306-318.

Burton, K. A. (1956). A study of the conditions and mechanisms of the diphenylamine reaction for the colorimetric estimation of deoxyribonucleic acid. Biochem. J. 62, 315-323.

Carson, S. H., Tausch, H. W., and Avery, M. E. (1973). Inhibition of lung cell division after hydrocortisone injection into fetal rabbits. J. Appl. Physiol. $34,660-663$.

Cox, M. A., and Torday, J. S. (1981). Pituitary oligopeptide regulation of phosphatidylcholine synthesis by fetal rabbit lung cells: Lack of effect with prolactin. Amer. Rev. Respir. Dis. 123, 181-184.

Dameron, F., and Marin, L. (1978). The endocrine control of embryonic lung maturation in the chicken. II. Role of the hypophysis. Anat. Embryol. 152, 235-241.

Doneen, B. A., and Smith, T. E. (1982a). Ontogeny of endocrine control of osmoregulation in chick embryo. I. Role of pituitary gland in distribution of water and ions among embryonic and extraembryonic compartments. Gen. Comp. Endocrinol. 48, 300-309.

Donecn, B. A., and Smith, T. E. (1982b). Ontogeny of endocrine control of osmoregulation in the chick embryo. II. Actions of prolactin, arginine vasopressin, and aldosterone. Gen. Comp. Endocrinol. 48, 310-318.

Fasman, G. D. (1976). "Handbook of Biochemical and Molecular Biology," 3rd Ed., Vol. II, p. 301. Chem. Rubber Co., Cleveland.

Feldman, D. A., Brubaker, P. G., and Weinhold, P. A. (1981). Activation of CTP: Phosphocholine citidyltransferase in rat lung by fatty acids. Biochim. Biophys. Acta 665, 53-59.

Folch, J., Lees, M., and Sloane-Stanley, G. H. (1957). A simple method for the isolation and purification of total lipides from animal tissues. J. Biol. Chem. 226, 497-509.

Fong, K., and Bockrath, R. C. (1977). Evidence for two modes of DNA degradation in Escherichia coli following ultraviolet irradiation. Radiat. Res. 72, 134-144.

Fugo, N. W. (1940). Effects of hypophysectomy in the chick embryo. J. Exp. Zool. 85, 271-297.

Fujiwara, T., Adams, F. H., Nozaki, M., and Dermer, G. B. (1970). Pulmonary surfactant phospholipids from turkey lung. Comparison with rabbit lung. Amer. J. Physiol. 218, 218-225.

Giannopoulos, G. (1974). Variations in the levels of cytoplasmic glucocorticoid receptors in lungs of various species of different developmental stages. Endocrinology 94, 450-458.

Gross, I., and Walker-Smith, G. I. (1978). Insulin delays the morphologic maturation of fetal rat lung in vitro. Pediatr. Res. 12, 515. 
Hamosh, M., and Hamosh, P. (1977). The effect of prolactin on the lecithin content of fetal rabbit lung. J. Clin. Invest. 59, 1002-1005.

Harvey, S., Davison, T. F., and Chadwick, A. (1979). Ontogeny of growth hormone and prolactin secretion in the domestic fowl (Gallus domesticus). Gen. Comp. Endocrinol. 39, 270-273.

Hylka, V. W. (1982). The surfactant system in the lung of the embryonic and juvenile chicken: Biochemical, ultrastructural, and endocrine studies. Ph.D. Dissertation, University of Michigan, Ann Arbor.

Hylka, V. W., and Doneen, B. A. (1980). Ontogeny and endocrine control of surfactant lipids in the embryonic chick lung. Amer. Zool. 20, 897. (Abstract No. 985).

Hylka, V. W., and Doneen, B. A. (1982). Lung phospholipids in the embryonic and immature chicken: Changes in lipid composition and biosynthesis during maturation of the surfactant system. $J$. Exp. Zool. 220, 71-80.

Kalliecharan, R., and Hall, B. K. (1974). A developmental study of the levels of progesterone, corticosterone, cortisol, and cortisone circulating in plasma of chicken embryos. Gen. Comp. Endocrinol. 24, 364-372.

Khosla, S. S., Gohran, I. I., and Rooney, S. A. (1980). Stimulation of phosphatidylcholine synthesis by $17-\beta$-estradiol in fetal rabbit lung. Biochim. Biophys. Acta 617, 282-290.

Kotas, R. V., and Avery, M. E. (1971). Accelerated appearance of pulmonary surfactant in the fetal rabbit. J. Appl. Physiol. 30, 358-361.

Liggins, G. C., and Kitterman, J. A. (1981). Development of the fetal lung. In "The Fetus and Independent Life" Ciba Found. Symp. 86, 308-330.

Lowry, O. H., Rosebrough, N. J, Farr, A. L., and Randall, R. J. (1951). Protein measurement with the Folin phenol reagent. J. Biol. Chem. 193, 265-275.

Marie-Schlienger, C., and Idelman, S. (1981). Evolution de la secretion en glucocorticoides de la surrenale chez l'embryon de poulet normal et apres decapitation tardive. C.R. Acad. Sci. (Paris) (D) 292, 313-318.

Marin, L., and Dameron, F. (1974). Differentiation de l'epithelium respiratoire chez l'embryon de poulet hypophysectomise par decapitation partielle. C.R. Acad. Sci. (Paris) (D) 279, 1685-1688.

Marin, L., Tordet, C., and Dameron, F. (1978). The endocrine control of embryonic lung maturation. I. Morphological and biochemical differentiation of lungs after "in ovo" decapitation. Anat. Embryol. 152, 223-234.

Mason, R. J., Nellenbogen, J., and Clements, J. A. (1976). Isolation of disaturated phosphatidylcholine with osmium tetroxide. J. Lipid Res. 17, 281284.
Massaro, D. (1981). The cellular and molecular basis of pulmonary alveolar stability. J. Lab. Clin. Med. 98, 155-165.

Meier, A. H., and Burns, J. T. (1976). Circadian hormone rhythms in lipid regulation. Amer. 2ool. 16 , 649-659.

Moog, R., and Richardson, D. (1955). The functional differentiation of the small intestine. IV. The influence of adrenocortical hormones on differentiation and phosphatase synthesis in the duodenum of the chick embryo. J. Exp. Zool. 130, 29-56.

Morishige, W. K. (1982). Thyroid hormone influences glucocorticoid receptor levels in the neonatal rat lung. Endocrinology 111, 1017-1019.

Morishige, W. K., and Uetake, C. A. (1978). Receptors for androgen and estrogen in the rat lung. Endocrinology 102, 1827-1837.

Nir, I., and Levy, V. (1973). Response of blood plasma glucose, free fatty acids, triglycerides, insulin and food intake to bovine insulin in geese and cockerels. Poult. Sci. 52, 886-892.

Pattle, R. E. (1978). Lung surfactant and lung lining in birds. In "Respiratory Function in Birds, Adult and Embryonic" (J. Piiper, ed.), pp. 23-32. Springer-Verlag, New York.

Smith, B. T., and Bogues, W. G. (1980). Effects of drugs and hormones on lung maturation in experimental animals and man. Pharmacol. Ther. 9, 51-74.

Smith, B. T., Giroud, C. J. P., Robert, M., and Avery, M. E. (1975). Insulin antagonism of cortisol action on lecithin synthesis by cultured fetal lung cells. J. Pediatr. 87, 953-955.

Smith, B. T., and Torday, J. S. (1974). Factors affecting lecithin synthesis by fetal lung cells in culture. Pediatr. Res. 8, 848-851.

Smith, B. T., Torday, J. S., and Giroud, C. J. P. (1974). Evidence for different gestation dependent effects of cortisol on cultured fetal lung cells. J. Clin. Invest. 53, 1518-1526.

Steel, R. G. D., and Torrie, J. H. (1980). "Principles and Procedures of Statistics. A Biometrical Approach," 2nd Ed., pp. 172-194. McGraw-Hill, New York.

Thommes, R. C, and Hylka, V. W. (1978). Plasma iodothyronines in the embryonic and immediate posthatch chick. Gen. Comp. Endocrinol. 35, 503.

Thommes, R. C., and Jameson, K. M. (1980). Hypothalamo-adeno-hypophyseal-thyroid interrelationships in the chick embryo. III. Total Ti levels in the plasma of decapitated chick embryos with adenohypophyseal transplants. Gen. Comp. Endocrinol. 42, 267-269.

Thommes, R. C., and Schulman, R. W. (1967). Endocrine control of lipid metabolisin in the developing chick embryo. I. Blood cholesterol. Gen. Comp. Endocrinol. 8, 54-60.

Thommes, R. C., and Tamborino, A. (1962). Effects 
of insulin administration upon blood-glucose levels of the chick embryo. Physiol. Zool. 35, 256-262.

Thommes, R. C., Vieth, R. L., and Levasseur, S. (1977). The effects of hypophysectomy by means of surgical decapitation on thyroid function in the developing chick embryo. I. Plasma thyroxine. Gen. Comp. Endocrinol. 31, 29-36.

Tordet, C., and Marin, L. (1976). Lipid and phospholipid content and fatty acid composition of the chick lung during embryonic development. Experientia $32,628-630$.

Touchstone, J. C., Chen, J. C., and Beaver, K. M.
(1980). Improved separation of phospholipids in thin layer chromatography. Lipids 15, 61-62.

Van Golde, L. M. G. (1976). State of the art. Metabolism of phospholipids in the lung. Amer. Rev. Respir. Dis. 114, 977-1000.

Woods, J. E., and Brazzill, D. M. (1981). Plasma 17$\beta$-estradiol levels in the chick embryo. Gen. Comp. Endocrinol. 44, 37-43.

Wu, B., Kikkawa, Y., Orzalesi, M., Motoyama, E., Kaibara, M., Zigas, C., and Cook, C. (1973). The effect of thyroxine on the maturation of fetal rabbit lungs. Biol. Neonate 22, 161-168. 